\title{
PLASMID PROFILING AND EFFECT OF DIFFERENT PHYSIOLOGICAL PARAMETERS ON THE CHROMIUM REDUCTION POTENTIAL OF MICROBES
}

\author{
Masooma Muzaffar \\ Department of Biology, Lahore Garrison University, Pakistan \\ Mawra Gohar \\ Department of Biology, Lahore Garrison University, Pakistan \\ Sumaira Mazhar* \\ Department of Biology, Lahore Garrison University, Pakistan \\ *Corresponding author \\ Email: smz.mmg@gmail.com
}

\begin{abstract}
Chromium is toxic for both human and aquatic life. It is recommended to eradicate from wastewaters or to alter its oxidation state to less toxic level The purpose of current research was to isolate heavy metal $(\mathrm{Cr})$ resistant bacteria from different industrial effluents (soil and waste water), to determine their potential for chromium reduction (CRP) at different parameters (time period, $\mathrm{pH}$, temperature and concentrations of chromium) and to determine the plasmid profiles of $\mathrm{Cr}$ (VI) resistant bacterial isolates. The growth of chromium resistant bacteria was determined by checking the influence of $\mathrm{pH}$, concentration of chromium, time period and temperature on isolates using UV spectrophotometer, while chromium reduction potential was also investigated using Deleo and Ehrlich method. Plasmid profiling was performed and analyzed using agarose gel electrophoresis $(0.8 \%)$ to determine the number, size and relationship of plasmid with heavy metal resistance. Results showed that the identified bacterial isolates ( $S$. aureus and $S$. epidermidis) were resistant to heavy metal $(\mathrm{Cr})$ confirmed by resistance profiling. The maximum growth of bacterial isolate was recorded after 24-hour incubation period (1.154), at pH 8 (1.512), temperature $37^{\circ} \mathrm{C}(1.615)$ and $500 \mu \mathrm{g} / \mathrm{mL}$ chromium concentration (1.978), while suitable conditions observed for chromium reduction potential was 24-hour incubation period (57\%), $\mathrm{pH}$ $7(62.6 \%)$, temperature $30^{\circ} \mathrm{C}(60 \%)$, and $500 \mu \mathrm{g} / \mathrm{mL}$ concentration of chromium $(60 \%)$. The plasmid profiles revealed that plasmid were randomly distributed among the bacterial isolates with average plasmid number (2.9) ranging from 0-5 and molecular size (100-12000bps). Overall, no defined relationship was observed among resistance pattern and plasmid mediated profiles.
\end{abstract}

Keywords: Chromium reduction potential, plasmid profiles, chromium resistant bacteria, heavy metal, \%age removal of chromium. 


\section{Introduction}

Heavy metal contamination in soil and water, is a serious environmental issue and of global health concern, particularly in developing countries (Kleckerova and Doeekalova, 2014; Akoto et al., 2014). Heavy metals are generally poisonous and can accumulate in living tissues causing various diseases (Abdominal pain, Nausea, Vomiting, Fatigue, Dehydration, Abnormal heart beat, Weakness, Skin and Lung irritability, etc.) and disorders (Lesions on Kidneys and Liver, Nervous system damage, Myocardium, Edema, etc.) in body posing a great threat to public health (Fu and Wang, 2011).

Chromium $\left(\mathrm{Cr}^{+6}\right)$ a well-documented toxin and carcinogen (Stearns, 2007) is one of the most potent heavy metal. Maximum tolerance level of chromium for the drinking water is $0.05 \mathrm{mg} / \mathrm{L}$ (Becquer et al. 2003). Hazards due to chromium contamination depend on its oxidation state and solubility (Shrivastava et al., 2002).

Many bacteria have specific genetic mechanisms of resistance to toxic metals (Mindlin, 2001) such as E. coli, Pseudomonas aeruginosa, Klebsiella pneumoniae, Staphylococcus aureus, Enterococcus faecalis, Bacillus thuringiensis, Micrococcus sp. (Agostinho, 2012). Chromium-resistant microbes are Pseudomonas aeruginosa, Bacillus sp., Pasteurella sp., Pseudomonas sp., E. coli and Staphylococcus sp. (Benmalek, 2012). Major illnesses caused by chromium resistive microbes include diarrhea, abdominal pain, fever, pneumonia (Melton, 2014), musculoskeletal infections, tissue necrosis, scalded skin syndrome, abscesses, impetigo, cellulitis etc. (Schlecht, 2015). The heavy metals degradation capacity of Micrococcus and Staphylococcus sp. might be plasmid mediated (Silver, 1988).

Plasmids are self-replicating, extra-chromosomal DNA molecules that exist in bacteria, allow parallel gene (heavy metal resistance) transmission by conjugation, transduction and alteration (Alam et al., 2010; Raj, 2012) between bacteria of identical or different genera (Wonglumsom et al., 2011).

Connubial transmission of plasmids is substantial in dispersal of resistant genes among bacterial strains (Cumhur and Ismet, 2014). Bacterial resistance to heavy metals and antibiotics was affirmed to be plasmid mediated (Seget et al., 2005; Jayaprakashvel et al., 2015). Former authors (Tewari, 2013; Al-Deeb, 2009) have reported plasmid mediated antibiotic resistance and heavy metal tolerance among the clinical as well as environmental (soil and water) bacterial isolates (Saumendra et al., 2016).

Plasmid profiling determines the number and size of plasmid in bacteria signifying the correlation between heavy metal resistances in bacteria with plasmid profile (heavy metal resistance genes). Detailed information about pathogenicity of the bacteria have been established through the plasmid profiling technique (Growther et al., 2012). To regulate the transmission structure of heavy metal resistance genes in bacterial cultures plasmid profiling was used widely as an epidemiological tool (Wonglumsom et al., 2011).

\section{Methodology}

\section{Isolation and screening of isolates}

Water and soil samples were collected from different industrial effluent sites, bacteria were isolated on Lagar plates which were purified and screened for further process.

\section{Resistance Profile}


Different concentrations of chromium were made in L-broth media (to find their effect on the growth of bacterial strains) poured in test tubes, inoculated with ( $0.5 \mathrm{McFarland}$ standard) purified test organisms and 24-hours incubation was given to the tube cultures with the two replicates prepared in the same manner at $37^{\circ} \mathrm{C}$. After 24 -hours, growth rate was measured by examining the volume of the isolates in tubes. The highly grown isolates were used for further process.

\section{Biochemical Characterization}

The bacterial isolates were identified microscopically, macroscopically and biochemically. Results were observed and documented.

\section{Physiological Characterization}

To examine the physiological characteristics of all the isolated cultures, Luria-broth was prepared, inoculated with chromium resistant isolates and incubated for different Time Periods (4, 8, 12, 16, 20, 24 hours), at different temperatures $\left(24^{\circ} \mathrm{C}, 30^{\circ} \mathrm{C}, 37^{\circ} \mathrm{C}, 42^{\circ} \mathrm{C}\right)$, different $\mathrm{pH}(5,6,7,8)$ levels and different chromium concentrations $(100$ $\mu \mathrm{g} / \mathrm{mL}, 500 \mu \mathrm{g} / \mathrm{mL}, 700 \mu \mathrm{g} / \mathrm{mL}, 1000 \mu \mathrm{g} / \mathrm{mL}$ ), to find their effects on the growth of isolates by measuring their optical density at $600 \mathrm{~nm}$ in spectrophotometer.

\section{Chromium Reduction Potential}

Chromium reduction potential of isolates was checked by Deleo and Ehrlich, (1994) method by using spectrophotometer. Cultures were grown in Luria-broth microfuge tubes with $500 \mu \mathrm{g} / \mathrm{mL}$ of hexavalent chromium for 24 hours and centrifuged for 10 minutes at $14,000 \mathrm{rpm}$. Then, $100 \mu \mathrm{L}$ of supernatant formed in cultural broth tubes were taken in autoclaved test tubes (having $10 \mathrm{~mL}$ of distilled water, $1 \mathrm{~mL}$ of Di-phenyl carbazide, 1 drop of phosphoric acid), O.D was taken at different time periods, temperature, $\mathrm{pH}$ and different concentrations of chromium using spectrophotometer $(540 \mathrm{~nm})$.

\section{Plasmid Profiling Technique \\ Plasmid Extraction}

After confirmation of isolates, plasmid was extracted using Phenol: chloroform: Isoamyl alcohol (25:24:1) method. The selected bacterial isolates were inoculated in $\mathrm{N}$-broth followed by incubation at $37^{\circ} \mathrm{C}$ for 24 hours. After incubation, overnight cultures $(0.5 \mathrm{~mL})$ were taken in a microfuge tube and projected to freeze thaw cycles ( 3 times). $0.5 \mathrm{ml}$ of phenol: chloroform: Isoamyl-alcohol (25:24:1) was added in broth containing microfuge tube and vortexed (14,000 rpm for 1 minute). TE buffer (10 Mm TrisCl, 7.5, $1 \mathrm{Mm}$ EDTA and $\mathrm{pH}$ 7.4) was used for saturating phenol prior to mixing with isoamyl alcohol and chloroform. Followed by the centrifugation at 12,000 rpm for 5 minutes, the upper aqueous phase $(0.45 \mathrm{~mL})$ was taken and moved to another microfuge tube containing $0.5 \mathrm{~mL}$ isopropanol, leaving the interphase undisturbed. The microfuge tube was thoroughly mixed before being centrifuged at $12,000 \mathrm{rpm}$ for 5 minutes.

After, discarding supernatant, the pellet was reconstituted with $0.5 \mathrm{~mL}$ of $70 \%$ ethanol by carefully adding along the side of the microfuge tube, and centrifugation was performed for 10 minutes at 14,000 rpm. The supernatant 
was again discarded, and the pellet was dried at room temperature. Then, $25 \mu \mathrm{L}$ of deionized water was added to the dried pellet and stored at $-20^{\circ} \mathrm{C}$ until required (Zhang and Cahalan, 2007).

\section{Preparation of Agarose Gel}

$0.8 \%$ of agarose gel was prepared by dissolving $0.8 \mathrm{gm}$ of agarose powder in $1 \mathrm{X}$ TAE (Tris-acetate-EDTA) buffer, making the final volume of $50 \mathrm{~L}$. In a microwave oven, the solution was boiled in short shots of around 20, 10, and 10 seconds. After allowing it to cool at $55^{\circ} \mathrm{C}, 3 \mu \mathrm{L}$ of ethidium bromide $(50 \mu \mathrm{g} / \mathrm{mL})$ was added to gel. Then the gel was poured into casting tray with combs already in place to make wells and it was allowed to solidify at room temperature.

\section{Plasmid Profiling}

The gel was removed carefully from casting tray after polymerization and placed in TAE buffer containing horizontal gel electrophoresis apparatus. Plasmid DNA $(7 \mu \mathrm{L})$ was combined with $3 \mu \mathrm{L}$ of loading dye to load the wells. To evaluate the size and number of plasmids in bacterial isolates, a DNA ladder $(3 \mu \mathrm{L})$ of $1 \mathrm{Kbps}$ was also loaded into the well. The electrophoresis apparatus was connected to a power supply, and current of $80 \mathrm{~V}$ was applied at room temperature for 45 minutes. The gel was removed from electrophoresis apparatus after the run time, and visualized under UV trans-illuminator and gel documentation system. The size and number of plasmid was determined by comparing with 1 kbps DNA ladder and results were recorded for further use (Farshad et al., 2012; Wonglumsom et al., 2011).

\section{Results}

\section{Isolation and Screening of isolates}

20 bacteria were isolated and purified; among them 10 bacteria were screened positive for heavy metal (chromium).

\section{Resistant profile}

Isolate $\mathrm{n}=10(33.3 \%) \mathrm{M}$, M2, M3, M4, M5, M6, M7, M8, M9 and M10 showed 100\% (maximum) good growth in all concentrations of chromium.

\section{Biochemical Characterization}

Isolates (Chromium resistant) were identified biochemically, microscopically and macroscopically. All bacterial isolates (100\%) were gram positive purple cocci (chains, clusters and diplococci), whereas presence of Staphylococcus aureus and Staphylococcus epidermidis species were identified microscopically and macroscopically.

\section{Physiological Characterization}

Physiological characterization of chromium resistant isolates was done by checking the effect of different time periods $\left(4^{\text {th }}, 8^{\text {th }}, 12^{\text {th }}, 16^{\text {th }}, 20^{\text {th }}\right.$ and $24^{\text {th }}$ hours) (Figure 1$)$, different temperatures $\left(24^{\circ} \mathrm{C}, 30^{\circ} \mathrm{C}, 37^{\circ} \mathrm{C}, 42^{\circ} \mathrm{C}\right)($ Figure 2), different $\mathrm{pH}(5,6,7,8)$ (Figure 3) and different concentrations of chromium $(100 \mu \mathrm{g} / \mathrm{mL}, 500 \mu \mathrm{g} / \mathrm{mL}, 700 \mu \mathrm{g} / \mathrm{mL}$, $1000 \mu \mathrm{g} / \mathrm{mL}$ ) (Figure 4) on the growth of chromium resistant isolates. Almost all of the isolates (100\%) showed 
maximum growth at $24^{\text {th }}$ hour of incubation, $37^{\circ} \mathrm{C}$ of temperature, $8 \mathrm{pH}$ and $500 \mu \mathrm{g} / \mathrm{mL}$ concentration of chromium at $600 \mathrm{~nm}$.

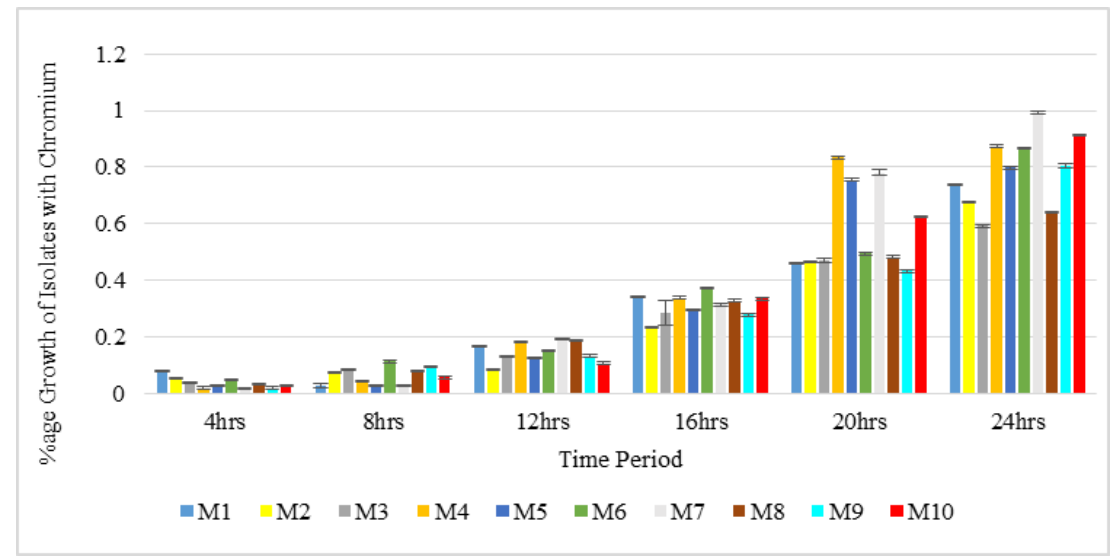

Figure1: Percentage growth of isolates with chromium at different time periods

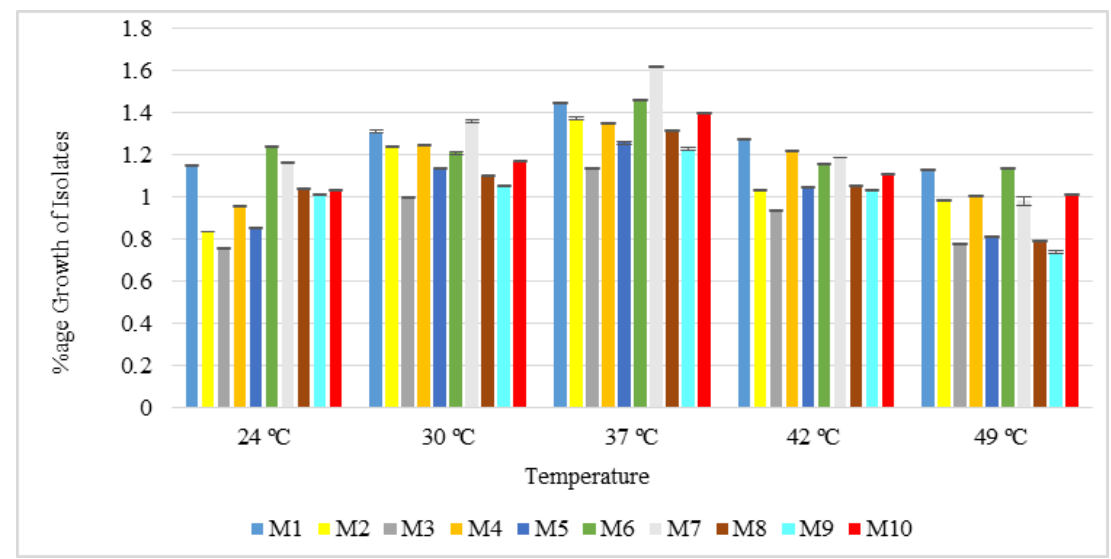

Figure 2: Percentage growth of isolates at different temperatures

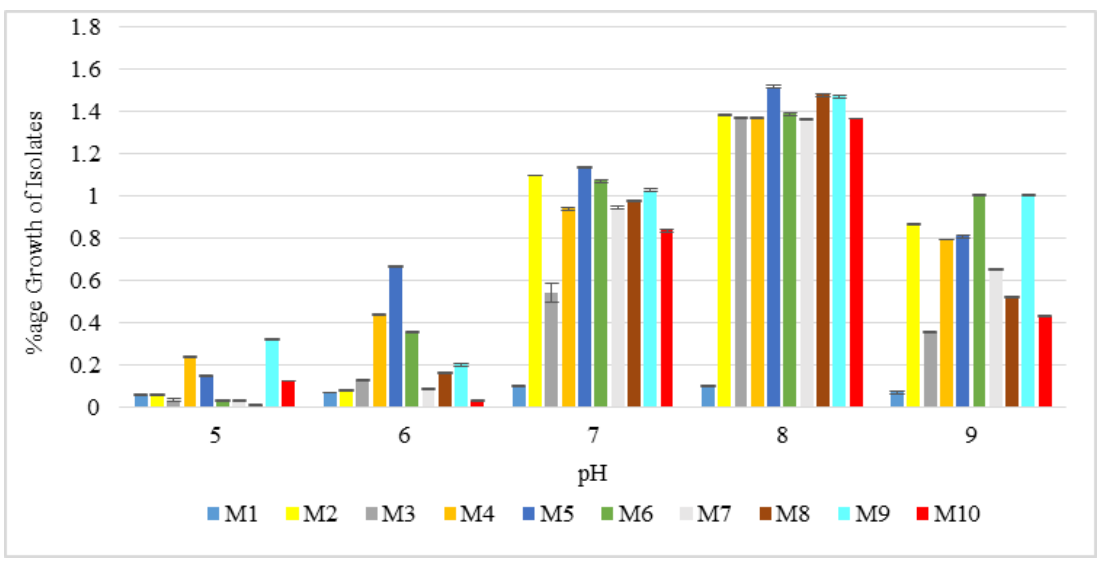

Figure 3: Percentage growth of isolates at different $\mathrm{pH}$ 


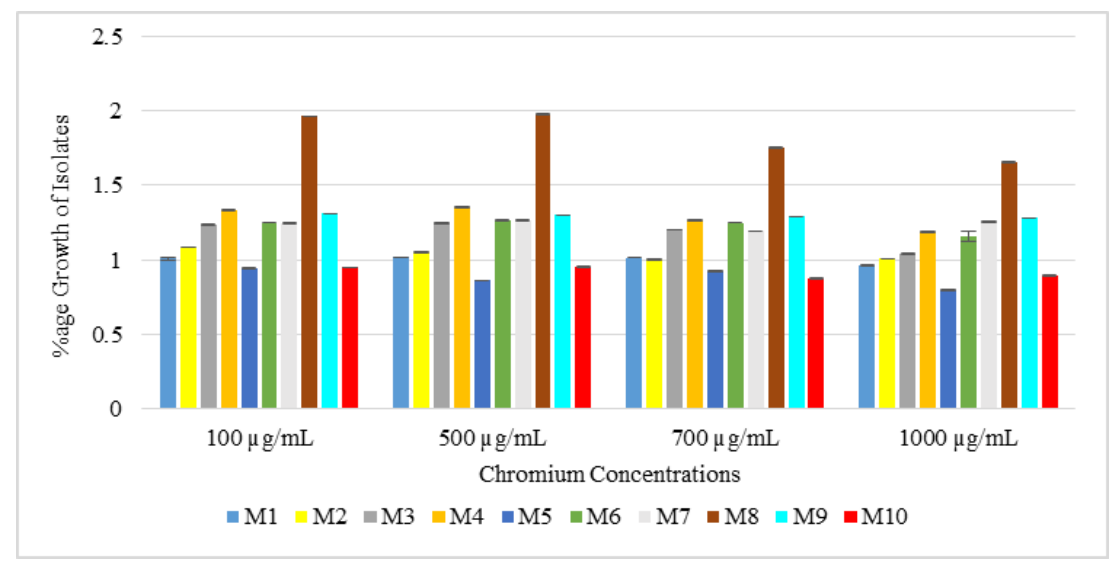

Figure 4: Percentage growth of isolates at different concentrations of chromium (VI)

\section{Chromium Reduction Potential}

Percentage removal of chromium metal at different time periods $(4,8,12,16,20$ and 24 hours) was done by following Deleo and Ehrlich, 1994 method (Figure 5). Reduction potential of chromium was highest at $24^{\text {th }}$ hour with average percentage of $43 \%$ followed by $20^{\text {th }}(39 \%)$ and $16^{\text {th }}$ hour $(35 \%)$ and lowest at $4^{\text {th }}$ hour of incubation, as the time passes the reduction rate increased to several folds. Results under mass spectrophotometer indicated that all of the isolates (under different temperatures and specific concentrations of chromium) showed maximum reduction percentage (average percentage of $58 \%$ ) at $30^{\circ} \mathrm{C}$ followed by $37{ }^{\circ} \mathrm{C}(49 \%)$ as shown in Figure 6. Maximum removal $\%$ age of chromium among isolates (under different $\mathrm{pH}$ and specific concentration of chromium) was at $\mathrm{pH} 7$ (56\%) followed by $\mathrm{pH} 8$ (44\%) (Figure 7). Maximum reduction was determined under $500 \mu \mathrm{g} / \mathrm{mL}$ (average percentage $=44 \%$ ) concentration of $\mathrm{Cr}^{+6}$ followed by $700 \mu \mathrm{g} / \mathrm{mL}$ (average percentage $=37 \%$ ), under $1000 \mu \mathrm{g} / \mathrm{mL}$ of chromium, the reduction $\%$ age was also noticeable (average percentage $=38 \%$ ) (Figure 8 ).

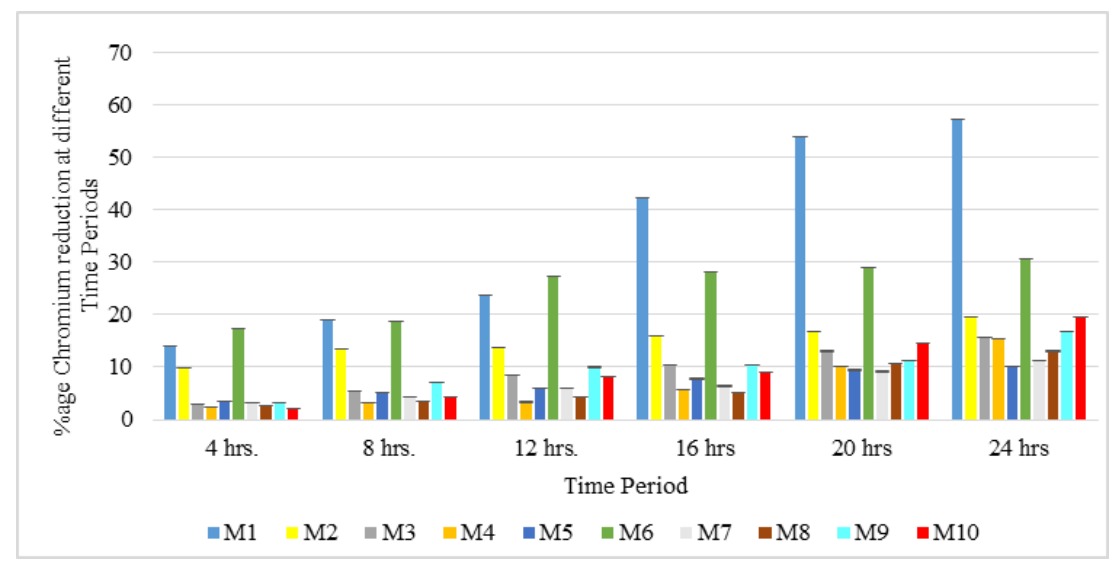

Figure 5: Percentage chromium reduction at different time periods 


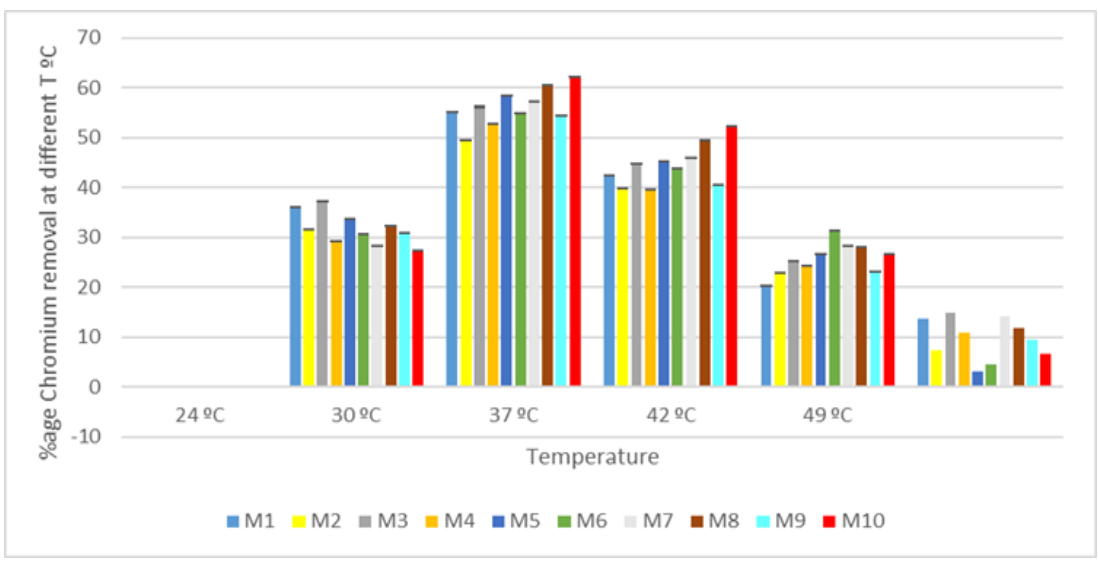

Figure 6: Percentage chromium reduction at different temperatures

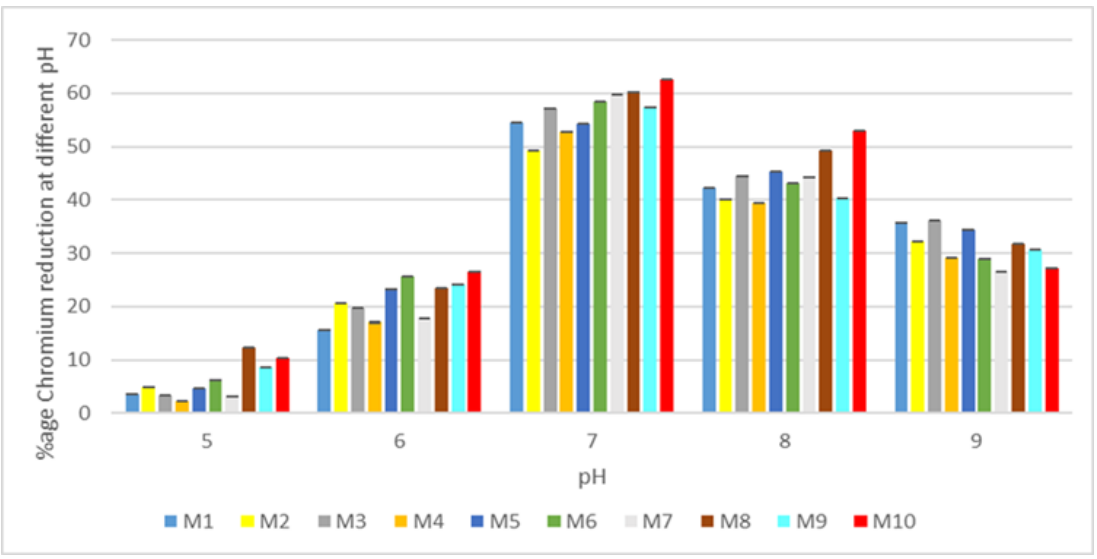

Figure 7: Percentage chromium reduction at different $\mathrm{pH}$

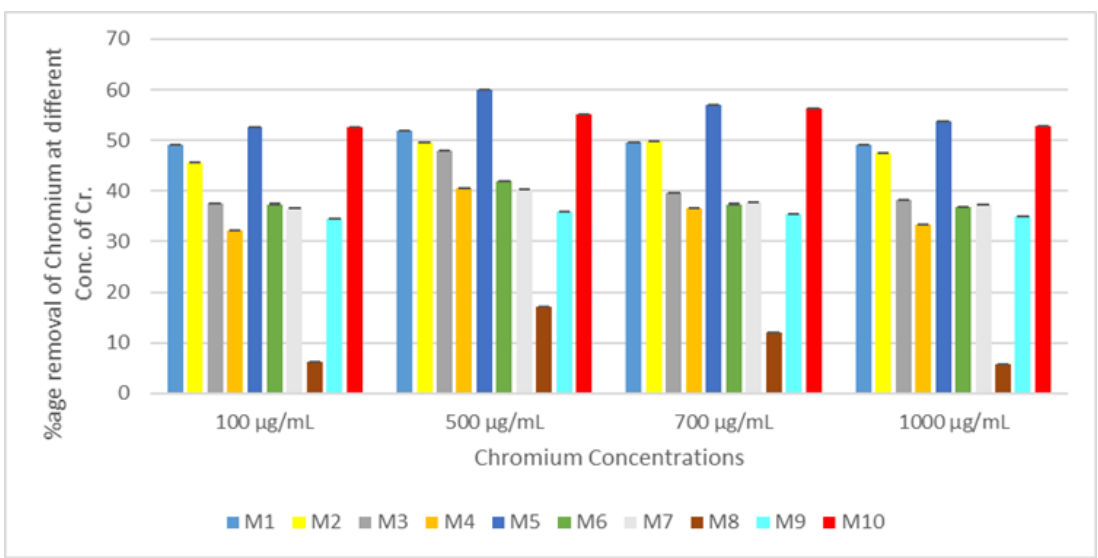

Figure 8: Percentage chromium reduction at different concentrations of chromium 


\section{Plasmid Profiling}

Plasmid profiling of bacterial isolates of industrial waste water and soil samples were performed and analyzed using agarose gel electrophoresis. The separation showed plasmid bands in different size and number as mentioned in Table 1.

Table 1: Plasmid profiles (number and size) of Staphylococcus sp.

\begin{tabular}{ccccccc}
\hline Sample ID & $\begin{array}{c}\text { No. of } \\
\text { plasmids }\end{array}$ & $\mathbf{1}$ & $\mathbf{2}$ & $\mathbf{3}$ & $\mathbf{4}$ & $\mathbf{5}$ \\
\cline { 3 - 7 } & 02 & 200 & - & - & - & 12,000 \\
\hline $\mathbf{1}$ & 04 & 200 & 800 & 1,200 & - & 12,000 \\
\hline $\mathbf{2}$ & 03 & 150 & 900 & 1,200 & - & - \\
\hline $\mathbf{3}$ & 02 & 300 & - & - & - & 11,000 \\
\hline $\mathbf{4}$ & 01 & - & - & - & - & 12,000 \\
\hline $\mathbf{5}$ & 03 & 200 & 800 & - & - & 11,000 \\
\hline $\mathbf{6}$ & 05 & 100 & 900 & 1,200 & 9,000 & 12,000 \\
\hline $\mathbf{7}$ & 00 & - & - & - & - & - \\
\hline $\mathbf{8}$ & 05 & 200 & 800 & 1,200 & 10,000 & 11,000 \\
\hline $\mathbf{9}$ & 04 & 150 & 800 & 1,200 & - & 12,000 \\
\hline $\mathbf{1 0}$ & & & & & & \\
\hline
\end{tabular}

Selected bacterial isolates $(\mathrm{n}=10)$ were subjected to plasmid mediated analysis and out of 10 bacterial isolates, 9 (90\%) were harboring the plasmid DNA. Many isolates were containing the same number and size of plasmid. Average plasmid number in selected bacterial isolates was 2.9 ranging from 0 to 5 . The highest number of plasmid was recorded in isolate 9 and 7 which was 5. Only one isolate (10\%) was harboring only 1 plasmid, two isolates (20\%) had 2 plasmids, two isolates (20\%) showed 3 plasmids, two isolates (20\%) had 4 plasmids, two isolates (20\%) harbored 5 plasmids and just one isolate (10\%) had no plasmid.

The size of plasmid was determined by comparing with DNA ladder (1 kbps). Plasmid DNA of different sizes ranging from 100-12000 bps were determined in selected isolates. The smallest plasmid size was 100 bps while the largest was 12000 bps which was observed in many bacterial isolates. A plasmid of $12000 \mathrm{~kb}$ was found in about half $(50 \%)$ of the isolates, either alone or combined with other plasmid bands of different sizes. The plasmid bands of sizes 150, 9,000, 10,000 and 11,000 kb were also analyzed. Almost 50\% isolates had plasmids of similar size i.e. 200, 1,200 and 12,000 bps. About 60\% isolates showed small size bands of plasmids (i.e. 100 bps, 200 bps or 300 bps). Plasmid bands of 800 bps, 900 bps, and 1200bps sizes were also found in various combinations in the isolates.

\section{Relationship of Plasmid Mediated Studies with Heavy Metal Resistance}

The relationship of current plasmid profiles and heavy metal resistance of selected bacterial isolates against different concentrations of chromium was determined, using current data collected on heavy metal resistance. Out of 10 S. aureus and S. epidermidis isolates, plasmid number $0(10 \%)$ and $1(10 \%)$ was observed in two isolates separately, showing moderate to high resistance profiles respectively. Two isolates (20\%) were highly resistant to different concentration of chromium (100 $\mu \mathrm{g} / \mathrm{mL}, 500 \mu \mathrm{g} / \mathrm{mL}, 700 \mu \mathrm{g} / \mathrm{mL}, 1000 \mu \mathrm{g} / \mathrm{mL})$ and were harboring two plasmids. Bacterial isolates (20\%) were containing 3 plasmids and resistant to high concentration of chromium ( $500 \mu \mathrm{g} / \mathrm{mL})$. 
The heavy metal resistance was in elevation against heavy metals $\left(\mathrm{Cr}^{+6}\right)$ in only two bacterial isolates (20\%) and plasmid copy number was 4 while bacterial isolates (20\%) were resistant to different concentrations of chromium and plasmid number was 5 . The plasmid copy number in current study was varying from isolate to isolate while the resistance pattern of heavy metal (Chromium) was almost same. All these bacterial isolates had different plasmid size (bps).

Overall plasmid profiles revealed that heavy metal resistance was plasmid or may be chromosomal mediated in some isolates. However, no significant relation was observed in heavy metal resistance with plasmid profiles.

\section{Discussion}

Chromium present in numerous oxidation statuses $(+2$ to +6$)$, but the most constant forms are $\mathrm{Cr}(0)$, Trivalent and Hexavalent chromium. Its toxicity makes it a primary environmental pollutant certainly present in air, water, soil and foodstuff (Avudainayagam et al., 2003). Cr (VI) is a potent skin irritant and carcinogenic (Park et al., 2004) for living organisms (Gonzalez et al., 2003), poisonous for herbs (plants), aquatic creatures (Velma et al., 2005) and microbes.

Hexavalent Chromium is 1000 times more toxicant than Trivalent Chromium due to its impermeability into cell membrane. The biological reduction of $\mathrm{Cr}$ (VI) to $\mathrm{Cr}$ (III) has been measured as a substitute procedure for the handling of $\mathrm{Cr}$ (VI) contaminated wastes due to its insolubility, which allows for its precipitation and elimination (Cervantes et al., 2001). Range of bacterial species have been stated, accomplished to reduce Hexavalent Chromium to Trivalent Chromium, comprising Bacillus sp. (Elangovan et al., 2006; Liu et al., 2006), E. coli (Bae et al., 2005), Microbacterium sp. (Pattanapipitpaisal et al., 2001a), Staphylococcus sp. (Rajbanshi et al., 2008) etc.

Staphylococcus sp. have been found abundantly in both water and soil, resistant to several classes of antimicrobial agents (Tavares and A.L., 2014). Antibiotic and heavy metal resistance genes can be found on plasmids and transposons, and they can be passed from one Staphylococcal species to another, as well as among Gram-positive bacteria (Werckenthin et al., 2001). Using a group of enzymes known as chromium reductases, Staphylococcus has ability to reduce chromium in both aerobic and anaerobic environments. Under aerobic conditions, $\mathrm{Cr}$ (VI) reduction is accomplished by soluble elements which use NADH as electron donor (Ackerley et al., 2004).

In recent study, the screened isolates were positive for chromium reduction potential (CRP). The CRP was determined by 1, 5-diphenylcarbazide method (Park et al., 2000). The categorization and optimization of different parameters such as different chromium concentrations, time period, $\mathrm{pH}$ and temperature was carried out to maximize growth and CRP of each isolate individually. During the present study the effect of different time periods, temperature, $\mathrm{pH}$ and different concentrations of chromium on the growth of chromium resistant bacteria was also checked. The maximum growth of chromium resistant isolates was observed at $24^{\text {th }}$ hour of incubation period, $37^{\circ} \mathrm{C}$ temperature with $\mathrm{pH} 8$ and $500 \mu \mathrm{g} / \mathrm{mL}$ concentration of chromium.

Current study also estimated reduction potential of chromium resistant bacteria with varying $\mathrm{pH}$, temperature, time period and concentrations of chromium. Results of present study indicated that the preferable time period for chromium reduction potential was 24 hours of incubation, notable temperature recorded for CRP was $30^{\circ} \mathrm{C}$, and 7 was the suitable $\mathrm{pH}$ for chromium reduction potential, whereas $500 \mu \mathrm{g} / \mathrm{mL}$ was the desirable concentration of chromium for chromium resistant bacteria. 
Plasmid profiles of present study showed average plasmid number 2.9 ranging from 0-5. Highest plasmid number harboring bacteria was 5, while the molecular size was determined using DNA ladder, ranging from 100$12000 \mathrm{bps}$ Overall, no consistent relation was found among plasmid profiles with heavy metal resistance.

\section{Conclusion}

Current study indicated that to reduce chromium (VI) to chromium (III) the preferable time period was 24 hours of incubation, notable temperature recorded for $\mathrm{CRP}$ was $30^{\circ} \mathrm{C}, 7$ was the suitable $\mathrm{pH}$, whereas $500 \mu \mathrm{g} / \mathrm{mL}$ was the desirable concentration of chromium for chromium resistant bacteria. Whereas, plasmid profiles revealed that plasmids were randomly distributed among the bacterial isolates. Overall, no defined relationship was observed among resistance pattern and plasmid mediated profiles. The current data is consistent with limited number of samples and bacterial isolates, more study and research is required to reveal the patterns.

\section{References}

Lima e Silva, A. A. D., Carvalho, M. A., de Souza, S. A., Dias, P. M. T., Silva Filho, R. G. D., Saramago, C. S., Bento, C. A. \& Hofer, E. 2012. Heavy metal tolerance (Cr, Ag and Hg) in bacteria isolated from sewage. Brazilian Journal of Microbiology, 43(4): 1620-1631.

Akoto, O., Bismark, E. F., Darko, G. \& Adei, E. 2014. Concentration and health risk assessments of heavy metals in fish from the Fosu Lagoon. International Journal of Environmental Research, 8(2): 403-410.

Avudainayagam, S., Megharaj, M., Owens, G., Kookana, R. S., Chittleborough, D. \& Naidu, R. 2003. Chemistry of chromium in soils with emphasis on tannery waste sites. Reviews of Environmental Contamination and Toxicology, 178: 53-91.

Ackerley, D. F., Gonzalez, C. F., Park, C. H., Blake, R. II., Keyhan, M. \& Matin, A. 2004. Chromate-reducing properties of soluble flavoproteins from Pseudomonas putida and Escherichia coli. Applied and Environmental Microbiology, 70: 873-882.

Alam, M. J., Rahman, M. T., Siddique, M. P., Khan, M. F. R. \& Rahman M. B. 2010. Antibiogram and plasmid profiling of E. coli isolates. International Journal of Biological Research, 1(3): 01-07.

Bae, W. C., Lee, H. K. \& Choe, Y. C. 2005. Purification and characterization of NADPH-dependent Cr (VI) reductase from Escherichia coli ATCC 33456. Journal of Microbiology, 43: 21-27.

Yamina, B., Tahar, B. \& Laure, F. M. 2012. Isolation and screening of heavy metal resistant bacteria from wastewater: a study of heavy metal co-resistance and antibiotics resistance. Water Science and Technology, 66(10): 2041-2048.

Becquer, T., Quantin, C., Sicot, M. \& Boudot, J. P. 2003. Chromium availability in ultramafic soils from New Caledonia. Science of the Total Environment, 30: 251-61. 
Cervantes, C., Campos-Gracia, J., Devras, S., Gutie'rrez-Corona, F., Loza-Tavera, H., TorresGuzma'n, J. C. \& Moreno-Sa'nchez, R. 2001. Interactions of chromium with microorganisms and plants. FEMS Journal of Microbiology Reviews, 25: 335-347.

Avşar, C. \& Berber, I. 2014. Plasmid profiling and antibiotics resistance of Escherichia coli strains isolated from Mytilus galloprovincialis and seawater. Journal of Coastal Life Medicine, 2(9): 689-693.

DeLeo, P. C. \& Ehrlich, H. L. 1994. Reduction of hexavalent chromium by Pseudomonas fluorescens LB300 in batch and continuous cultures. Journal of Applied Microbiology and Biotechnology, 40(5): 756-759.

Elangovan, R., Abhipsa, S. \& Rohit, B. 2006. Reduction of Cr (VI) by a Bacillus sp. Biotechnology Letters, 28: 247252.

El-Deeb, B. 2009. Plasmid mediated tolerance and removal of heavy metals by Enterobacter sp. American Journal of Biochemistry and Biotechnology, 5(1): 47-53.

Farshad, S., R. Ranjbar, A., Japoni, M., Hosseini, M., Anvarinejad, M. \& R. Mohammadzadegan, R. 2012. Microbial susceptibility, virulence factors, and plasmid profiles of uropathogenic Escherichia coli strains isolated from children from Jahrom, Iran. Archives of Iranian Medicine, 15(5): 312-316.

Fu, F. \& Wang, Q. 2011. Removal of heavy metal ions from wastewaters: a review. Journal of Environmental Management, 92(3): 407-418.

Gonzalez, C. F., Ackerley, D. F., Park, C. H. \& Matin, A. 2003. A soluble flavoprotein contributes to chromate reduction and tolerance by Pseudomonas putida. Acta Biotechnologica, 2: 233-239.

Jayaprakashvel, M., Vijay, S., Karthigeyan, C. P. \& Hussain, A. J. 2015. Isolation and characterization of mercury resistant marine bacteria from the coastal area of Chennai, India. International Journal of Advanced Research in Engineering and Applied Sciences, 4: 64-76.

Kleckerova, A. \& Doeekalova,H. 2014. Dandeliton plants as a biomonitor of urban area contamination by heavy metals. International Journal of Environmental Research, 8(1): 157-164.

Liu, Y. G., Xu, W. H., Zeng, G. M. 2006. Cr (VI) reduction by Bacillus sp. isolated from chromium landfill. Process Biochemistry, 41(9): 1981-1986.

Melton-Celsa, A. R. 2014. Shiga Toxin (Stx) classification, structure, and function. Microbiology Spectrum, 2(2): 3753.

Mindlin, S., Kholodii, G., Gorlenko, Z., Minakhina, S., Minakhin, L., Kalyaeva, E., Kopteva, A., Petrova, M., Yurieva O. \& Nikiforov, V. 2001. Mercury resistance transposons of gram-negative environmental bacteria and their classification. Research in Microbiology, 152(9): 811-822. 
Park, C. H., Keyhan, M. \& Wielinga, B. 2000. Purification to homogeneity and characterization of a novel Pseudomonas putida chromate reductase. Applied and Environmental Microbiology, 66(5): 1788-1795.

Park, R. M., Bena, J. M. \& Stayner L. T. 2004. Hexavalent chromium and lung cancer in the chromate industry: A quantitative risk assessment. Microbial Risk Analysis, 24(5): 1099-1108.

Pattanapipitpaisal, P., Brown, N. L. \& Macaskie, L. E. 2001. Chromate reduction and 16S rRNA identification of bacteria isolated from a $\mathrm{Cr}(\mathrm{VI})$ contaminated site. Journal of Applied Microbiology and Biotechnology, 57(1): 257261.

Rajbanshi, A. 2008. Study on heavy metal resistant bacteria in Guheswori sewage treatment plant. Our Nature, 6(1): $52-57$.

Raj, A. 2012. Antibiotic resistance, plasmid and RAPD profiles of multidrug-resistant Escherichia coli form bacteria isolated from sewage samples of Ghaziabad city, India. Universal Journal of Environmental Research and Technology, 2(4): 318-324.

Mandal, S., Das, S. N. \& Mandal, M. 2016. Plasmid mediated antibiotic and heavy metal co-resistance in bacterial isolates from Mahananda River Water (Malda, India). Journal of Translational Medicine, 6(185): 1025-2161.

Schlecht, L. M., Peters, B. M., Krom, B. P., Freiberg, J. A., Hänsch, G. M., Filler, S. G., Jabra-Rizk, M. A. \& Shirtliff, M. E. 2015. Systemic Staphylococcus aureus infection mediated by Candida albicans hyphal invasion of mucosal tissue. Microbiology, 16 (1): 168-181.

Seget, P. Z., Cycoń, J. \& Kozdrój, J. 2005. Metal tolerant bacteria occurring in heavily polluted soil and mine spoil. Applied Soil Ecology, 28(3): 237-246.

Shrivastava, P. K. \& Gupta S. K. 2014. Removal of chromium from waste water by adsorption method using agricultural waste materials. International Journal of Chemical Sciences and Applications, 6(1): 1-5.

Silver, S. \& Misra, T. K. 1988. Plasmid-mediated heavy metal resistances. Annual Reviews in Microbiology, 42(1): 717-743.

Stearns, D. M. 2007. Chapter 3-Multiple hypotheses for chromium (III) biochemistry: why the essentiality of chromium (III) is still question. In: Vincent, J.B. (Ed.), The Nutritional Biochemistry of chromium (III). Elsevier, 57-70.

Tewari, S., Ramteke, P. W., Tripathi, M., Kumar, S. \& Garg, S. K. 2013. Plasmid mediated transfer of antibiotic resistance and heavy metal tolerance in thermos-tolerant water borne coliforms. African Journal of Microbiology Research, 7(2):130-136 
Tavares, A. L. 2014. Community-associated methicillin-resistant Staphylococcus aureus (CA-MRSA) in Portugal: Origin, epidemiology and virulence. Reviews on Environmental Health, 24(2): 129-145.

Werckenthin, C., Cardoso, M., Martel, J. L. \& Schwarz, S. 2001. Antimicrobial resistance in staphylococci from animals with particular reference to bovine Staphylococcus aureus, porcine Staphylococcus hyicus and canine Staphylococcus intermedius. Veterinary Research, 32: 341-362.

Wonglumsom, W., Sianglum, W., Tiyasuttipan, W. and Sirisali, S. 2011. Plasmid profiles and antimicrobial resistance patterns of Escherichia coli. Royal Thai Army Medical Journal, 64(4): 175-180.

Zhang, S. and M. D. Cahalan. 2007. Purifying plasmid DNA from bacterial colonies using the Qiagen Miniprep Kit. Journal of Visualized Experiments, (6): e247. 